\title{
Combining ability and heterosis for grain yield, fodder yield and other agronomic traits in sorghum [Sorghum bicolor (L.) Moench]
}

\author{
Sushil Kumar* and Pooran Chand \\ Agriculture and Technology. Meerut-250110 (U.P.), INDIA \\ *Corresponding author. E-mail: sushil_svbp@rediffmail.com \\ Received: February 27, 2015; Revised received: September 24, 2015; Accepted: December 8, 2015
}

Sorghum Quality Laboratory, Department of Genetics and Plant Breeding, Sardar Vallabhbhai Patel University of

\begin{abstract}
Forty five hybrids derived from a diallel mating design of ten parents and one standard check PUSA CHARI-121 were evaluated for general and specific combining ability effects and standard heterosis for grain yield/ plant, dry fodder yield/plant, days to 50 per cent flowering, plant height, number of leaves/plant, leaf length, leaf breadth and 100- seed weight of Sorghum bicolor. The mean square due to general and specific combining ability was significan for Days to $50 \%$ flowering, Days to maturity, Plant height $(\mathrm{cm})$, No of Leaves/plant, Leaf length $(\mathrm{cm})$, Leaf width $(\mathrm{cm})$, seed yield/plant $(\mathrm{g})$, Fodder yield/plant $(\mathrm{q} / \mathrm{ha})$ and 100 -seed weight $(\mathrm{g})$ for all the characters. Both additive and non additive genetic effects were present in the material under study. However the ratio of $\sigma^{2} \mathrm{gca} / \sigma^{2} \mathrm{sca}$ suggested that the preponderance of non additive gene action in expression of all the characters under study. Out of the nine parents PUSA CHARI-121, PANT CHARI-4, MP CHARI, PANT CHARI-6 and PANT CHARI-5 identified as good general combiner for grain yield/plant, dry fodder yield/plant and other agronomical traits. The hybrid HC-136 $\mathrm{X}$ PANT CHARI-4 and PANT CHARI-4 x PUSA CHARI-121 for grain yield/plant and hybrid MP CHARI x PANT CHARI -6, PANT CHARI-5 x SPV 1616 and HC-136 x PANT CHARI-4 for dry fodder yield/plant exhibited higher magnitude of positive significant specific combining ability effect with highest standard heterosis and per se performance. These hybrids were also found suitable for two or three yield contributing traits. In general, close association between specific combining ability effects and standard heterosis was observed among the best hybrids identified on the basis of specific combining ability effects for grain and dry fodder yield.
\end{abstract}

Keywords: Combining ability, Diallel analysis, Gene action,, Sorghum, Standard heterosis

\section{INTRODUCTION}

Sorghum [Sorghum bicolor (L.) Moench] is an often self-pollinating, diploid $(2 \mathrm{n}=2 \mathrm{x}=20)$ crop with a genome, about $25 \%$ the size of maize or sugarcane. It is a C4 plant with higher photosynthetic efficiency and higher abiotic stress tolerance (Nagy et al., 1995; Reddy et al., 2009). Sorghum is fifth most important cereal crop globally and is the dietary staple of more than 500 million people in 30 countries. It is grown on $40 \mathrm{~m}$ ha in 105 countries of Africa, Asia, Oceania and the Americas. Africa and India account for the largest share $(>70 \%)$ of global sorghum area while USA, India, Mexico, Nigeria, Sudan and Ethiopia are the major sorghum producers (Kumar et al., 2011; Kumar and Chopra, 2013). It is the third most important grain crop in India, next only to rice (Oryza sativa) and wheat (Triticum aestivum). Maharashtra, Karnataka, Madhya Pradesh, Andhra Pradesh, Rajasthan Gujarat and UP are the major sorghum growing states of India. Besides being an important food, feed and forage crop, sorghum also provides raw material for the production of starch, fiber, dextrose syrup, biofuels, alcohol, and other products (Kumar and Chopra, 2013). Classical plant breeding has resulted in the successful development of high yielding, highly adapted sorghum cultivars. Vast diversity is available in sorghum and it is distributed among different sorghum races. Therefore, further enhancement of yield potential and the productivity of newly developed varieties needs urgent attention. The traits like grain and fodder yield are governed by polygenes with complex gene action and hence understanding the nature and magnitude of gene action help the breeder in selection of an appropriate breeding method such as biparental mating and recurrent selection was suggested. by Hayes and Garber in 1919. For improvement in such an important crop, the most important prerequisite is the selection of suitable parents, which could combine well and produce desirable hybrids and segregants. In the present study, an attempt has been made to estimate the heterosis in F1 hybrids with respect to yield, the combining ability and gene action governing the quantitative traits in sorghum, S. bicolor using diallel mating designs.

\section{MATERIALS AND METHODS}

The ten genetically diverse lines of sorghum presented in table 1 were crossed in diallel mating design exclud- 
Table 1. Origin and pedigree of sorghum genotypes used for the diallel cross.

\begin{tabular}{lll}
\hline Cultivar & Origin/Source & Pedigree \\
\hline 1-PANT CHARI-5 & GBPUA\&T Pantnagar (U.K) & CS 3541 X IS 6953 \\
2-PUSA CHARI-1002 & IARI New Delhi & xxxxxxxxxxxxxx \\
3-SPV 1616 & DSR Hyderabad (Andra Pradesh) & SPV 946 x Kh 89-246 \\
4-PUSA CHARI-615 & IARI New Delhi & xxxxxxxxxxxxxxx \\
5-HC-136 & GBPUA\&T Pantnagar (U.K) & IS 3214 (biolor) x PC 7R \\
6-PANT CHARI-4 & GBPUA\&T Pantnagar (U.K) & IS 4776 x Rio \\
7-PUSA CHARI-121 & IARI New Delhi & xxxxxxxxxxxxxxxx \\
8-MP CHARI & GBPUA\&T Pantnagar (U.K) & xxxxxxxxxxxxxx \\
9-PANT CHARI-6 & GBPUA\&T Pantnagar (U.K) & Selection from SDSL 92140 \\
10-HC-171 & GBPUA\&T Pantnagar (U.K) & SPV 8 x IS 4776 \\
\hline
\end{tabular}

ing reciprocals to produce 45 experimental hybrids during kharif 2012. The $45 \mathrm{~F}_{1 \mathrm{~s}}$ including Ten parents and a popular local check PUSA CHARI-121 were grown at the Crop Research Center of Sardar Vallabhbhai Patel University of Agriculture \& Technology, Meerut (U.P.) during kharif 2012. University is situated at latitude of $29.5^{\circ} \mathrm{N}$ and longitude $77.45^{\circ} \mathrm{E}$ and at an elevation of $237 \mathrm{M}$ above the Mean Sea Level. The experiment was laid out in randomized block design with three replication in a single-row plot of $6.75 \mathrm{~m}$ long, spaced at $0.45 \mathrm{~m}$ apart. NPK 120:40:00 fertilizers was applied as half basal dose of nitrogen and full dose of phosphorus at the time of sowing and half nitrogen applied after one month of sowing. Plots were thinned down after two weeks of crop emergence and plant-to-plant distance of $0.15 \mathrm{~m}$ was maintained. All other recommended agronomical practices were followed to raise a good crop. The biometrical observations recorded on grain yield/plant $(\mathrm{g})$, dry fodder yield/plant $(\mathrm{g})$, plant height $(\mathrm{cm})$, number of leaves/ plant, leaf length $(\mathrm{cm})$, leaf breadth $(\mathrm{cm})$ and 100- seed weight (g) on five randomly selected competitive plants of each genotype and each replication. The observation for days to $50 \%$ flowering and days to maturity were recorded on the plot basis. The mean values of observations were subjected to diallel analysis to estimate general combining ability (gca) and specific combining ability (sca) effects as per procedure given by Griffing method 2 Model I (Griffing, 1956) and standard heterosis was calculated as per standard procedure given by Meredith and Bridge (1972). Analysis of variance (ANOVA) was performed to test the significance of differences among the genotypes including crosses and parents as per standard procedure given by Panse and Sakhatme (1964).

\section{RESULTS AND DISCUSSION}

The analysis of variance revealed significant variability among the parents and hybrids for all the nine characters studied. For efficient selection, presence of variability among the genotypes for the traits of interest is a prerequisite. The analysis of variance for combining ability revealed the significant mean square due to general and specific combining ability for all the characters under study (Table 2). This indicates that all the characters contribute much for genetic variability among the parents and hybrids and both additive and none additive gene effects were important for the expression of these traits. However the variance due to specific combining ability was greater than the variance due to general combining ability, which indicated the predominant role of non additive gene action in the expression of these traits. Predominance of nonadditive gene action for these traits in sorghum was observed by Pillai et al. (1995), Badge and Patil (1997), Baghel et al. (2005), Premlatha et al. (2006), Solanki et al. (2007), Mohamed and Talib (2008) and Aruna et al. (2010), Vinaykumar (2011). Harer and Bapat (1982) stated that the per se performance of the parents with high general combining ability provide the criteria for the choice of parents for hybridization. On this basis, those parents which performed well for per se performance and general combining ability effects can be considered as desirable parents. Further the parents with high gca effects are desirable for obtaining useful segregants in early generations. The potentiality of parents to produce better offspring's with superior genes was evaluated based on their general combining ability effect. To get desirable recombinants in segregation generations, the parents of the hybrids must be good general combiner for the characters to which improvement is sought Kulkarni et al. (2007), Gravois and McNew, 1993). The estimate of general combining ability effects for different diverse parents revealed that none of the nine lines showed desirable significant general combining ability effects for all the traits together indicating that different parent should be used for genetic improvement of different yield components (Table 3 ). In the present study, different parental lines have been identified with good general combining ability for different yield and yield related traits. Considering the both general combining ability effects and per se performance, the parental lines PUSA CHARI-121, PANT CHARI-4 and MP CHARI with moderate to high per se performance and high significant positive general combining effect for grain yield and 100- seed weight indicate that these lines are good for grain yield/plant. While the parental lines PANT CHARI-6, PUSA CHARI-121, PANT CHARI-5 and MP CHARI showed high per se performance and high significant positive general combining effect for dry fodder yield. Apart from grain and fodder yield some parents also registered significant general combining ability effect in desirable direction 
Sushil Kumar and Pooran Chand / J. Appl. \& Nat. Sci. 7 (2) : 1001 -1005 (2015)

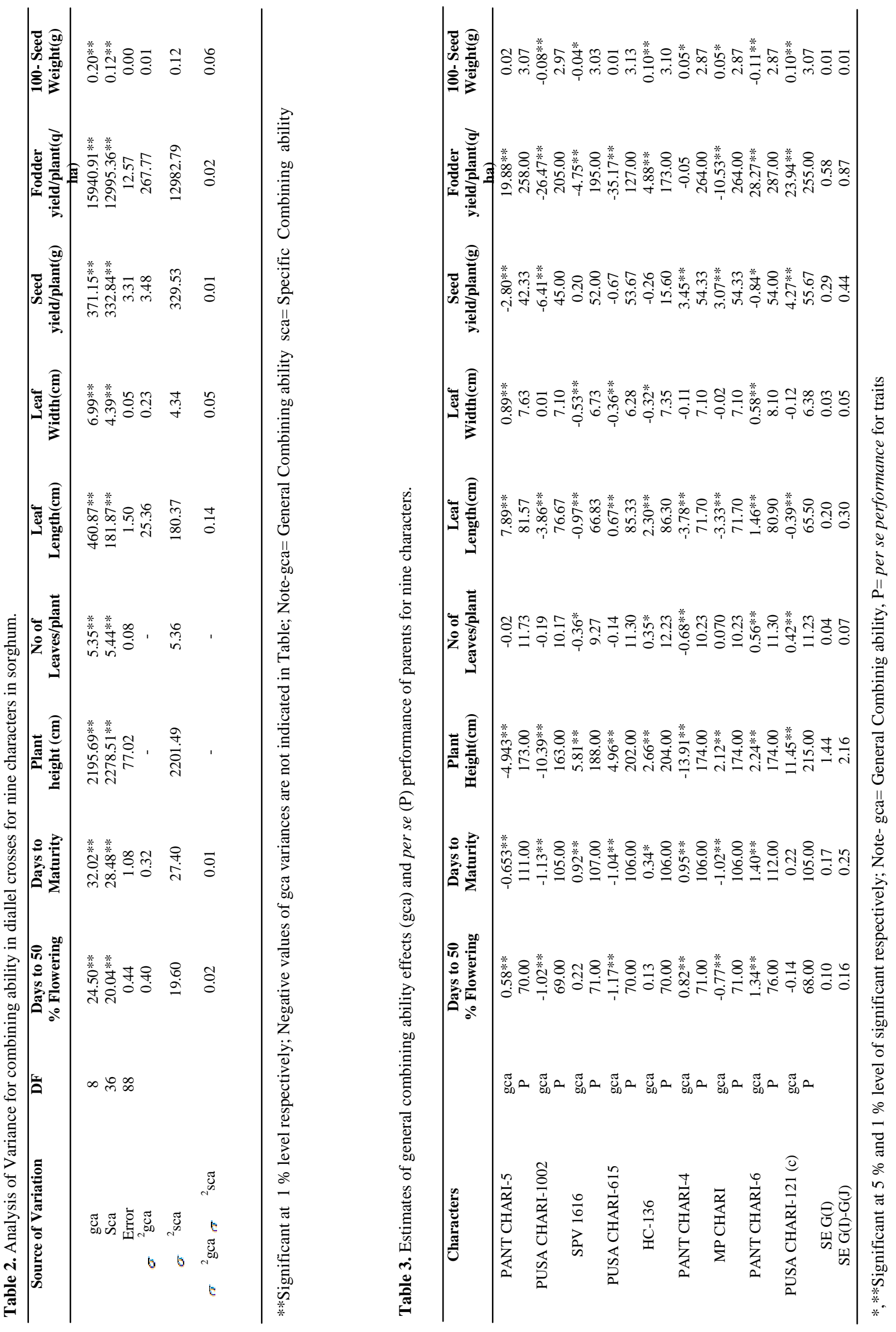




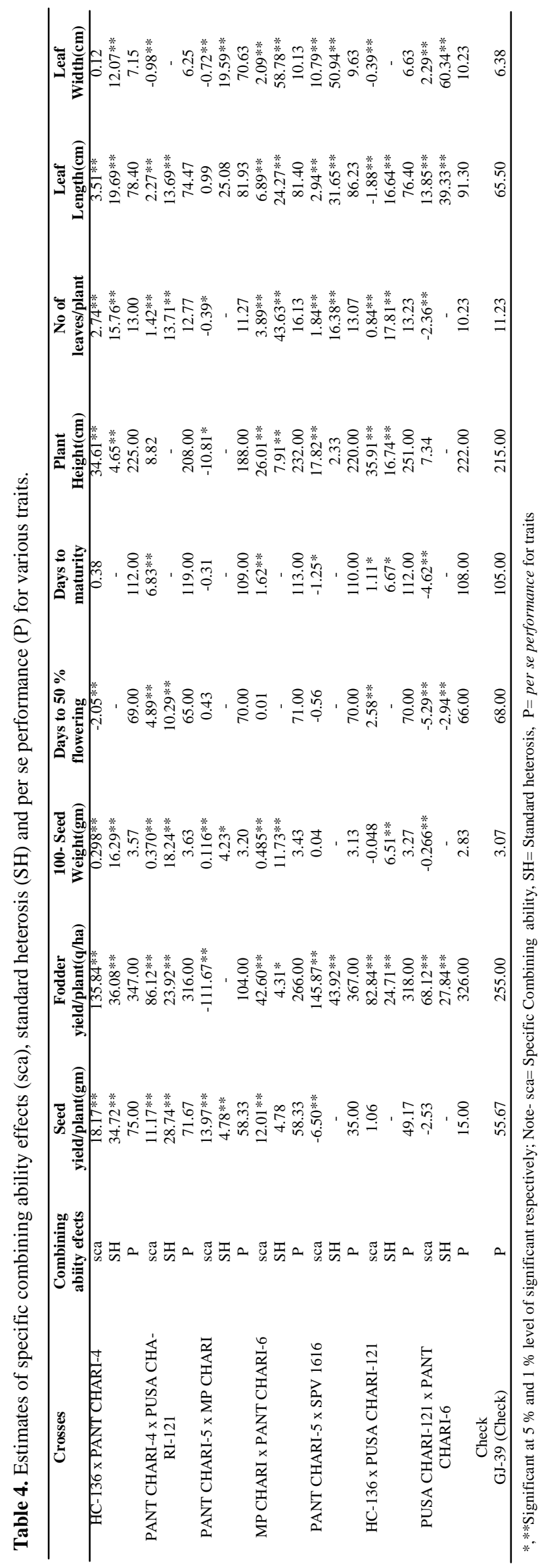

for other traits like days to $50 \%$ flowering and maturity (PUSA CHARI-615, PUSA CHARI-1002 and MP CHARI), number of leaves (HC-136, PUSA CHARI121 and PANT CHARI-6), leaf length and width (PANT CHARI-5 and PANT CHARI-6) (Table 3). Thus, it would be worthwhile to use above parents in breeding programme for exploiting additive gene effects. Similar results were reported by earlier workers in sorghum (Prakash et al., 2010; Mahdy et al., 2011). A perusal of best hybrids on the basis of significant positive specific combining ability effects and standard heterosis for grain and dry fodder yield revealed that hybrid HC-136 x PANT CHARI-4 exhibits highest magnitude of positive significant specific combining ability effect for grain yield/plant along with the highest magnitude of standard heterosis for grain yield/ plant against the popular local check PUSA CHARI121 (Table 4). This hybrid also exhibited positive significant specific combining ability effect and standard heterosis for dry fodder yield/plant, 100-grain weight, plant height, number of leaves/plant and leaf length. It was in fact a cross of poor $x$ good general combining ability effect parent for seed yield/plant. A high $\mathrm{x}$ high general combining ability effect hybrid PANT CHARI -4 x PUSA CHARI-121 showed significant high positive specific combining ability effects and standard heterosis for grain yield/plant, fodder yield/plant, 100grain weight, number of leaves/plant, leaf length. Other important hybrids for grain yield/plant was PANT CHARI-5 x MP CHARI and MP CHARI $x$ PANT CHARI-6 which exhibited significant high positive specific combining ability effects and standard heterosis for grain yield/plant and 100-seed weight (Table 4). Both the hybrid involved one good combiner and one poor combiner for grain yield. Such occurrence of good hybrids by the combination of one good combiner and one poor combiner may be due to accumulation of favorable genes and partly due to dominance and recessive interaction.

On the basis of higher significant positive specific combining ability effect in relation to standard heterosis for dry fodder yield/plant revealed that hybrid PANT CHARI-5 x SPV 1616 recorded the high specific combining ability effects for dry fodder yield/ plant. This hybrid also exhibited positive significant specific combining ability effect for plant height, number of leaves/plant, leaf length and leaf width. It was derived from high $\mathrm{x}$ low parental combinations for dry fodder yield/plant and exhibited highest positive standard heterosis and per se performance for dry fodder yield/plant.

Another important hybrid for dry fodder yield/plant was HC-136 x Pusa Chari-121 and PUSA CHARI-121 x PANT CHARI-6 (Table 4). Both hybrids were a derivative of high $\mathrm{x}$ high parental combinations in terms of general combining ability and these hybrids might produce desirable segregants. Hence, these hybrids might be desirable for biparental selection or intermating. These hybrids appeared in the top ranking hybrids 
with high specific combining ability effects and exhibited highest positive standard heterosis and per se performances for dry fodder yield/plant. High specific combining ability and standard heterosis for grain yield/plant and dry fodder yield and their related traits were observed in Sorghum by Prakash et al. (2010) and Mahdy et al. (2011). In general parental lines and all the hybrids possessed good per se performance and combining ability effects for grain and dry fodder yield and other agronomic traits. The result indicated that the heterosis for grain and dry fodder yield can be exploited commercially. It is apparent the good $\mathrm{x}$ poor, poor $\mathrm{x}$ good and good $\mathrm{x}$ good general combiners depicted high specific combining ability effect indicating the role of the dominance gene action.

\section{Conclusion}

Thus, it can be concluded that both inter and intra allelic interactions were involved in the expression of plant height, number of leaves/plant, leaf length and leaf width. The parental lines in this study were having diverse genetic background of their source populations, and hence their hybrids exhibited high specific combining ability effects along high standard heterosis for grain and dry fodder yield/plant. Hence, the heterosis for grain and dry fodder yield can be exploited commercially in forage sorghum.

\section{REFERENCES}

Aruna, C., Audilakshmi, S. and Chandrasekara Reddy, D. (2010). Evaluation of sorghum [Sorghum biecolor (L.) Moench] germplasm lines for their yield components. Indian J. Agric. Sci., 80: 409-412.

Badge, P.L. and Patil, H.S. (1997). Line $\mathrm{x}$ Tester analysis in sorghum [Sorghum biecolor (L.) Moench]. Ann.Agric. Res., 18: 281-284.

Baghel, B.R.S., Chaudhary, Lata and Sharma, Vithal (2005). Combining ability analysis over the envirements for harvest index and its components in Sorghum [Sorghum biecolor (L.) Moench]. Indian J.of Genetics and Plant Breeding, 65 (4): 315-316

Gravois, K.A. and McNew, W.R. (1993). Genetic relationships and selection for rice yield and yield components.Crop Sci., 33: 249-252.

Griffing, B. (1956). Concept of general and specific combining ability in relation to diallel crossing system. Aust. $J$. Biol. Sci., 9: 463-493.

Harer, P.N. and Bapat, D.R. (1982). Line x tester analysis of combining ability in grain sorghum. J. Maharashtra Agric. Univ., 7: 230-232.

Hayes, H.K., and R.J.Garber. (1919). Synthetic production of high protein corn in relation to breeding. J. Amer. Soc. Agron.,11: 308-318.

Kumar, A.A., Reddy, B.V.S., Ramaiah, B. and Sharma, R. (2011). Heterosis in white-grained grain mold resistant sorghum hybrids. SAT J. Agric. Res., 9: 1-6.

Kumar, V. and Chopra, A.K. (2013). Response of sweet sorghum after fertigation with sugar mill effluent in two seasons. Sugar Tech, DOI 10.1007/s12355-013-0226-9

Kulkarni, Vikas., Salimath, P.M. and Patil, M.S. (2007). Combining ability analysis in Rabi Sorghum [Sorghum biecolor (L.) Moench]. Crop Research, 4:8-16.

Mahdy, E.E., Ali, M.A. and Mahmoud, A.M. (2011). The effect of environment on combining ability and heterosis in grain sorghum (Sorghum bicolor L. Moench). Asian J. Crop Sci., 3: 1- 15.

Meredith, W.R. and Bridge, R.R. (1972). Heterosis and gene action in cotton (Gossypium hirsutum L.). Crop. Sci., 12: 304-310.

Mohamed, M.I. and Talib, N.H. (2008). Heterosis and combining ability for quality traits in sorghum [Sorghum biecolor(L.) Moench]. Aust. J. Basic Appl. Sci., 2: 99104.

Nagy, Z.Z., Tuba, F. Soldos, Z. and Erdei, L. (1995). CO2Ex- change and Water Relation Responses of Sorghum and Maize during Water and Salt Stress. J. Plant Physiol., 145:539-544.

Panse, V.G. and Sakhatme, P.V. (1964). Statistical methods for Agricultural workers, 2 nd Edn, ICAR, New Delhi. $361 \mathrm{p}$.

Pillai, M.A., Rangaswamy, P., Nadarajan, N., Vanniarajan, C. and Ramalingam, J. (1995). Combining ability analysis for panicle characters in sorghum. Indian J. Agric. Res., 29: 98-102.

Prakash, R., Ganesamurthy, K., Nirmalakumari, A., Nagarajan, P. (2010). Combining ability for fodder yield and its components in Sorghum (Sorghum bicolor L. Moench). Electron. J. Plant Breed., 1: 124-128

Premlatha, N., Kumar, N. and Veerabadhiran, P. (2006). Heterosis and combining ability for grain yield and its components in sorghum [Sorghum biecolor (L.) Moench]. Indian J. Genet., 66: 123-126.

Reddy, B.V.S., Ramesh, S., Reddy, P.S. and Kumar, A.A. (2009). Genetic Enhancement for Drought Tolerance in Sorghum. Plant Breed. Rev., 31:189-222.

Solanki, B.G., Patel, D.M., Patel, P.B. and Desai, R.T. (2007). Combining ability analysis in Sorghum [Sorghum biecolor (L.) Moench] Crop Research. Hisar. 33 (1/3): 187-191.

Vinaykumar, R., Jagadeesh., B.N., Talekar, S., Sandeep, R. G. and Rao, M.R.G. (2011). Combining ability of parents and hybrids for juice yield and its attributing traits in sweet sorghum (Sorghum bicolor L.). Electronic J. Plant Breed., 2 (1):41-46. 